\title{
A Study on the Current Situation of Parenting Stress of Mothers of 0-3 Year-old Young Children in Chongqing
}

\author{
Nan Jiang, Xiaofen Liu \\ School of Pre-school Education of Chongqing University of Education, Chongqing 400067, China \\ Corresponding author Email: jiangnan@cque.edu.cn
}

\begin{abstract}
Parenting stress not only affects the physical and mental health of the mother, but also affects the harmony of the family. In terms of young children, excessive parenting stress will prevent the mother from raising the young children in a better way. Especially under the implementation of the universal two-child policy, the unsatisfactory population growth is also related to the mother's parenting stress. Therefore, this research selects the mothers of 0-3 year-old young children in Chongqing as the research object to survey the current situation of parenting stress of mothers of 0-3 year-old young children through questionnaires, and proposes corresponding countermeasures.
\end{abstract}

Keywords: 0-3 year-old young children, mothers, parenting stress, current situation

\section{FOREWORD}

With the overall opening of the national "universal two-child policy", the parenting issues of two-child families have received more and more attention, and the parenting stress has gradually become the focus of social attention. Influenced by the traditional idea of "men make houses; women make homes", mothers devote more effort to raising children, and are prone to parenting stress in child rearing. 0-3 years old is a critical period for young children to establish a sense of security and an important stage for the formation of a good attachment relationship. As the main caregiver of the children, mothers have primary influence on the establishment of attachment of young children and the establishment of the sense of security and trust. The mother's physical and mental health will directly affect the preschool children's physical and mental development, and the degree of mother's parenting stress will also have a certain impact on the physical and mental development of young children. Therefore, this research conducted a survey on the parenting stress of mothers of $0-3$ year-old young children in Chongqing to understand the current situation of mothers' parenting stress, find out the existing problems, and put forward suggestions to reduce the mothers' parenting stress.

\section{RESEARCH OBJECT AND RESEARCH METHODS}

\subsection{Research object}

A simple random sampling method was adopted for the main urban area of Chongqing. A total of 300 questionnaires were distributed and 279 were collected. A total of 255 valid questionnaires were sorted out and the effective rate was $85 \%$. Among them, there were 111 respondents having male children and 144 having female children; there were 108 respondents whose children aged $0-1,66$ whose children aged 1-2, and 81 whose children aged 2-3; 177 had natural labour, and 78 had no natural labour.

\subsection{Research methods}

This research mainly adopts the research method of questionnaire survey, and selects the PSI simplified Chinese version questionnaire revised by Taiwan scholar Weng Yuxiu in 2011. The questionnaire contains 36 questions, all of which are single choice questions. The questionnaire includes 7 dimensions including parenting constraints, ego loss, husband assistance, parenting expectations, parenting anxiety, parent-child interaction disorder and community support, and the five-level scoring system is adopted, that is, "strongly agree, agree, uncertain, disagree, and strongly disagree. The scores are" $5,4,3,2,1$ ". The questionnaire has good reliability and validity. The overall $\alpha$ coefficient of the questionnaire is 0.753 , ranging from 0.7 to 0.8 . The reliability of each dimension is parenting constraints, ego loss, husband assistance, parenting expectations, parenting anxiety, parent-child interaction disorder and community support: $0.843,0.755,0.718,0.879,0.855,0.741$, and 0.686 ; the questionnaire reliability is good. The KMO value is 0.831 , which is higher than 0.8 , indicating that the questionnaire has high validity.

\section{RESEARCH RESULTS}

\subsection{The overall level of mothers' parenting stress}

As can be seen from Table 3.1, the parent-child interaction 
disorder has the highest score, with an average score of 3.53; followed by the parenting anxiety dimension, with an average score of 3.46; the average scores for parenting expectations and ego loss are 3.36 and 3.09, respectively; the average scores of husband assistance, community support and parenting constraints are 3.07, 2.91 and 2.68, respectively.

\section{TABLE 3.1 OVERALl SituATION OF MOTHERS' PARENTING STRESS}

\begin{tabular}{|c|c|c|c|}
\hline Dimension & Question number & $\begin{array}{c}\text { Average } \\
\text { value }\end{array}$ & $\begin{array}{c}\text { Standard } \\
\text { deviation }\end{array}$ \\
\hline $\begin{array}{c}\text { Parenting } \\
\text { constraints }\end{array}$ & $2,3,4,5$ & 2.68 & 0.88 \\
\hline Ego loss & $1,9,10,11,12$ & 3.09 & 0.84 \\
\hline $\begin{array}{c}\text { Husband } \\
\text { assistance }\end{array}$ & $6,7,8$ & 3.07 & 0.88 \\
\hline $\begin{array}{c}\text { Parenting } \\
\text { expectations }\end{array}$ & $18,19,20,21,30,35$ & 3.36 & 0.91 \\
\hline $\begin{array}{c}\text { Parenting } \\
\text { anxiety }\end{array}$ & $13,15,16,25,26,27,28,36$ & 3.46 & 0.84 \\
\hline $\begin{array}{c}\text { Parent-child } \\
\text { interaction } \\
\text { disorder }\end{array}$ & $14,22,23$ & 3.53 & 0.97 \\
\hline $\begin{array}{c}\text { Community } \\
\text { support }\end{array}$ & $31,32,33$ & 2.91 & 0.94 \\
\hline
\end{tabular}

\subsection{The impact of parenting constraints on mothers' parenting stress}

As can be seen from Table 3.2, in the dimension of parenting constraints, the highest score on the topic of "I can hardly do what I like since I have children" is 3.12 points, and $44.71 \%$ of mothers said that they had this phenomenon. $38.82 \%$ of mothers said, "Since I have children, I can no longer try new and different things". It can be seen that most mothers think that having a child restrains the identity of the mother, which is a lot more stressful than the role of the father.

TABLE 3.2 SPECIFIC QUESTION SCORES OF THE PARENTING CONSTRAINTS DIMENSION

\begin{tabular}{|c|c|c|}
\hline Item & $\begin{array}{c}\text { Average } \\
\text { value }\end{array}$ & $\begin{array}{c}\text { Standard } \\
\text { deviation }\end{array}$ \\
\hline $\begin{array}{c}\text { In order to meet the needs of my child, } \\
\text { I sacrificed a lot. That is what I did not } \\
\text { expect }\end{array}$ & 2.45 & 1.01 \\
\hline $\begin{array}{c}\text { Since I have children, I feel bound by } \\
\text { parental responsibility }\end{array}$ & 2.35 & 1.11 \\
\hline $\begin{array}{c}\text { Since I have children, I can no longer } \\
\text { try new and different things }\end{array}$ & 2.79 & 1.12 \\
\hline $\begin{array}{c}\text { Since I have children, I can hardly do } \\
\text { what I like }\end{array}$ & 3.12 & 1.12 \\
\hline
\end{tabular}

\subsection{The impact of community support on mothers' parenting stress}

As can be seen from Table 3.3, in the dimension of community support, the highest score on the topic of "Children often disobey me and I think helpless but no one can help" is $3.20 .50 .59 \%$ of mothers said that such a thing would happen. This is a manifestation of the lack of community software support and family relationships, as well as mothers' parenting knowledge. It can be seen from this that the community parenting environment has an important impact on the mothers' total parenting stress.

TABLE 3.3 SPECIFIC QUESTION SCORES OF THE COMMUNITY SUPPORT DIMENSION

\begin{tabular}{|c|c|c|}
\hline Item & $\begin{array}{c}\text { Average } \\
\text { value }\end{array}$ & $\begin{array}{c}\text { Standard } \\
\text { deviation }\end{array}$ \\
\hline $\begin{array}{c}\text { I'm often troubled by children's } \\
\text { education problems }\end{array}$ & 2.82 & 1.10 \\
\hline $\begin{array}{c}\text { It is inconvenient to take the } \\
\text { children out, and it is difficult to } \\
\text { find a room of mother and infant }\end{array}$ & 2.72 & 1.16 \\
\hline $\begin{array}{c}\text { Children often disobey me and I } \\
\text { think helpless but no one can help }\end{array}$ & 3.20 & 1.03 \\
\hline
\end{tabular}

\subsection{The impact of husband assistance on mothers' parenting stress}

As can be seen from Table 3.4, in the dimension of husband assistance, the highest score on the topic of "I am always taking care of children by myself" is 3.27. $49.41 \%$, $29.41 \%$ and $48.24 \%$ of the mothers said, "I am always taking care of children by myself", "There are too many things in my life that bother me", and "I did not expect that this child was born to cause so many problems to marriage bonds". These three topics reflect the marriage bonds and marital status. Good marriage bonds can effectively reduce the mothers' parenting stress.

TABLE 3.4 SPECIFIC QUESTION SCORES OF THE Husband ASSistance Dimension

\begin{tabular}{|c|c|c|}
\hline Item & $\begin{array}{c}\text { Average } \\
\text { value }\end{array}$ & $\begin{array}{c}\text { Standard } \\
\text { deviation }\end{array}$ \\
\hline I am always taking care of children \\
by myself & 3.27 & 1.10 \\
\hline $\begin{array}{c}\text { There are too many things in my } \\
\text { life that bother me }\end{array}$ & 2.73 & 1.16 \\
\hline $\begin{array}{c}\text { I did not expect that this child was } \\
\text { born to cause so many problems to } \\
\text { marriage bonds }\end{array}$ & 3.20 & 1.03 \\
\hline \multicolumn{2}{|c|}{} & \\
\hline
\end{tabular}

\subsection{The impact of ego loss on mothers' parenting stress}

As can be seen from Table 3.5, in the dimension of ego loss, the highest score on the topic of "I feel lonely, and I have no friend" is $3.42 .60 \%, 45.88 \%$ and $44.71 \%$ of the mothers said, "I feel lonely and I have no friend", "I usually don't have a good time when I go to parties", and "I don't enjoy things like I used to, and I don't enjoy life". Through data analysis, it is found that the change of roles has caused huge changes in women's lives, and their attention has gradually come around their children. 
TABLE 3.5 SPECIFIC QUESTION SCORES OF THE EGO LOSS DIMENSION

\begin{tabular}{|c|c|c|}
\hline Item & $\begin{array}{c}\text { Average } \\
\text { value }\end{array}$ & $\begin{array}{c}\text { Standard } \\
\text { deviation }\end{array}$ \\
\hline $\begin{array}{c}\text { I often don't feel that I can } \\
\text { handle things well }\end{array}$ & 2.71 & 1.09 \\
\hline $\begin{array}{c}\text { I feel lonely and I have no } \\
\text { friend }\end{array}$ & 3.42 & 1.07 \\
\hline $\begin{array}{c}\text { I usually don't have a good } \\
\text { time when I go to parties }\end{array}$ & 3.12 & 1.09 \\
\hline $\begin{array}{c}\text { I don't like to communicate } \\
\text { with others like I used to }\end{array}$ & 3.14 & 1.10 \\
\hline $\begin{array}{c}\text { I don't enjoy things like I used } \\
\text { to, and I don't enjoy life }\end{array}$ & 3.07 & 1.12 \\
\hline
\end{tabular}

\subsection{The impact of parenting expectations on mothers' parenting stress}

As can be seen from Table 3.6, in the dimension of parenting expectations, the highest score on the topic of "My child does not like smiling like others" is $3.81 .60 \%$, $55.24 \%$ and $55.29 \% \%$ of the mothers said, "My child seems to learn slower than the average children", "My child can do much less than I thought" and "My child usually needs a long time to adapt to new things". The data shows that children are expected to reach a certain level, and often too high expectations lead to increased parenting stress on mothers.

TABLE 3.6 SPECIFIC QUESTION SCORES OF THE PARENTING EXPECTATIONS DIMENSION

\begin{tabular}{|c|c|c|}
\hline Item & $\begin{array}{c}\text { Average } \\
\text { value }\end{array}$ & $\begin{array}{c}\text { Standard } \\
\text { deviation }\end{array}$ \\
\hline $\begin{array}{c}\text { My child seems to learn slower than } \\
\text { the average children }\end{array}$ & 3.54 & 1.11 \\
\hline $\begin{array}{c}\text { My child does not like smiling like } \\
\text { others }\end{array}$ & 3.81 & 1.14 \\
\hline $\begin{array}{c}\text { My child can do much less than I } \\
\text { thought }\end{array}$ & 3.39 & 1.18 \\
\hline $\begin{array}{c}\text { My child usually needs a long time to } \\
\text { adapt to new things }\end{array}$ & 3.39 & 1.16 \\
\hline $\begin{array}{c}\text { My child does not sleep or eat in fixed } \\
\text { time, and it is much more difficult to } \\
\text { develop a fixed timetable than I } \\
\text { expected }\end{array}$ & 2.95 & 1.16 \\
\hline $\begin{array}{c}\text { I want my child to do something or } \\
\text { stop doing something }\end{array}$ & 3.11 & \\
\hline
\end{tabular}

\subsection{The impact of parenting anxiety on mothers' parenting stress}

As can be seen from Table 3.7, in the dimension of parenting anxiety, the highest score on the topic of "My child rarely does something making me happy" is 3.85 . $67.06 \%, 71.76 \%$ and $56.64 \%$ of the mothers said, "My child smiles at me much less than I expected", "When I devote my energy to this child, I feel that my efforts are in vain" and "My child is usually in a bad mood when he wakes up". The data show that parenting anxiety is one of the parenting stresses of mothers.

TABLE 3.7 SPECIFIC QUESTION SCORES OF THE PARENTING ANXIETY DIMENSION

\begin{tabular}{|c|c|c|}
\hline ITEM & $\begin{array}{c}\text { AVERAGE } \\
\text { VALUE }\end{array}$ & $\begin{array}{c}\text { STANDARD } \\
\text { DEVIATION }\end{array}$ \\
\hline $\begin{array}{c}\text { MY CHILD RARELY DOES } \\
\text { SOMETHING MAKING ME HAPPY }\end{array}$ & 3.85 & 1.01 \\
\hline $\begin{array}{c}\text { MY CHILD SMILES AT ME MUCH LESS } \\
\text { THAN I EXPECTED }\end{array}$ & 3.68 & 1.12 \\
\hline $\begin{array}{c}\text { WHEN I DEVOTE MY ENERGY TO } \\
\text { THIS CHILD, I FEEL THAT MY } \\
\text { EFFORTS ARE IN VAIN }\end{array}$ & 3.73 & 1.20 \\
\hline $\begin{array}{c}\text { MY CHILD IS USUALLY IN A BAD } \\
\text { MOOD WHEN HE WAKES UP }\end{array}$ & 3.45 & 1.05 \\
\hline $\begin{array}{c}\text { I THINK THIS KID IS VERY } \\
\text { EMOTIONAL AND OFTEN UNHAPPY }\end{array}$ & 3.38 & 1.09 \\
\hline $\begin{array}{c}\text { MY CHILD WILL DO SOMETHING } \\
\text { THAT BOTHERS ME }\end{array}$ & 3.20 & 1.13 \\
\hline $\begin{array}{c}\text { MY CHILD WILL REACT STRONGLY } \\
\text { TO THINGS HE DOESN'T LIKE }\end{array}$ & 2.76 & 1.15 \\
\hline $\begin{array}{c}\text { PLEASE THINK CAREFULLY AND } \\
\text { CALCULATE HOW MANY BEHAVIORS } \\
\text { OF YOUR CHILD BOTHER YOU (SUCH } \\
\text { AS PARTIAL ECLIPSE, FIGHTS, } \\
\text { DISOBEDIENCE, TOO ACTIVE, LIKE } \\
\text { CRYING, LIKE DISTURBING OTHERS, } \\
\text { INAPPROPRIATE BEHAVIOR, AND } \\
\text { BAD TEMPER) }\end{array}$ & 3.62 & 1.27 \\
\hline
\end{tabular}

\subsection{The impact of parent-child interaction disorder on mothers' parenting stress}

As can be seen from Table 3.8, in the dimension of parent-child interaction disorder, the highest score on the topic of "I don't think my child likes me and close to me in most of the time" is 3.86. $64.71 \%$ of mothers said, "I am troubled because I can't cultivate a closer and warmer relationship with this child". The data show that most mothers are stressed when it comes to parent-child interaction disorder.

TABLE 3.8 SPECIFIC QUESTION SCORES OF THE PARENT-CHILD INTERACTION DISORDER DIMENSION

\begin{tabular}{|c|c|c|}
\hline Item & $\begin{array}{c}\text { Average } \\
\text { value }\end{array}$ & $\begin{array}{c}\text { Standard } \\
\text { deviation }\end{array}$ \\
\hline $\begin{array}{c}\text { I don't think my child likes me } \\
\text { and close to me in most of the } \\
\text { time }\end{array}$ & 3.86 & 1.07 \\
\hline $\begin{array}{c}\text { I am troubled because I can't } \\
\text { cultivate a closer and warmer } \\
\text { relationship with this child }\end{array}$ & 3.51 & 1.22 \\
\hline $\begin{array}{c}\text { Sometimes my child will } \\
\text { deliberately do something that } \\
\text { makes me very angry }\end{array}$ & 3.21 & 1.24 \\
\hline
\end{tabular}




\section{RESEARCH CONCLUSION}

\subsection{Insufficient parenting knowledge of mothers}

Children aged 0 to 3 are considered to be extremely psychologically and physiologically dependent on their mothers, and 0 to 3 years old is a critical period for the growth of young children ${ }^{[1]}$. Therefore, understanding the parenting knowledge and familiarizing with the specific needs of young children will not only increase the mothers' confidence in child rearing, but also enable the healthy growth of young children. Most of the mothers said, "My child does not sleep or eat in fixed time, and it is much more difficult to develop a fixed timetable than I expected". These problems reflect the lack of parenting knowledge or the unscientific value and methods of child rearing. Young children will be in the opposite state to their expected development, which greatly increases the parenting stress of mothers.

\subsection{Lack of understanding and care from family members}

At present, many newborn mothers have the responsibility and obligation of the mother after the birth of the child, linking everything to themselves. Especially for mothers who have a cesarean section, any problem with the child is more likely to cause guilt as the mother subconsciously think the problem is caused by themselves. The sense of parenting constraints is strong, which creates higher stress. In addition, there is a lack of the identity of the husband as father. Many families have "widowed parenting" ${ }^{[2]}$. The husband's "absence" makes the mother live in onerous childcare and family work, making the mother lose enthusiasm for other things and easy to regard the child as the whole life, and lose their identity.

\subsection{Social policy support and welfare support are not in place}

Perfect supporting facilities and welfare policies will help reduce the parenting stress of mothers. Especially after China's "universal two-child policy", population growth is still slow. The main reason is that the cost of having children is too high ${ }^{[3]}$. The parents of young children are mostly the generation after 90 s, and most of them are only child. The pressure on life is high, and most families are only willing to raise one child. Although the state has certain subsidies for childbirth allowance, there are many restrictions, and the childbirth allowance can be negligible in the face of high bearing costs and raising costs. In terms of maternity leave, although domestic maternity leave increased from 90 days to 98 days, compared with Japan, Russia and other countries, the domestic maternity leave is still short

\section{SUGGESTIONS}

\subsection{Enrich their own recreational activities and parenting knowledge}

It is necessary to enrich their own recreational activities. After being a mother, in addition to taking care of the children, they can spend the rest of their time chatting with friends or developing their own hobbies. This can effectively save themselves from the parenting stress, reduce the sense of parenting constraints, facilitate their physical and mental pleasure and maintain a good mood. In addition, the mother should cultivate a positive and optimistic attitude. They should be able to transfer stress in face of stress and seek help. Last but not least, they should learn parenting knowledge. Mothers can browse through the Internet, follow the Wechat official account and participate in lectures by experts and scholars, not only to study by themselves, but also to lead their family members to participate in it, so as to achieve a consistent educational perspective. ${ }^{[4]}$ Scientific parenting knowledge can effectively improve the efficiency of mothers taking care of children and reduce the anxiety of blind parenting.

\subsection{Family members give enough help and care}

Every novice mother is a mother for the first time, and has no experience in babysitting. At this time, family members play a very important role, especially the husband. In the future care and raising of the child, the father's participation plays a very important role in the child's character and mental health, and the husband's understanding and assistance to the mother will greatly reduce the mother's parenting stress. It is not recommended that the elders interfere excessively with the novice mother, and they should give the new family more room. ${ }^{[5]}$ Finally, giving mother enough help and care will deepen the marriage bonds and enhance the feelings among the families. In the long run, it will be very conducive to the development of all aspects of the family.

\subsection{Government provides childcare benefits}

First of all, the government can carry out relevant activities through community organizations, such as setting up a special nursery in the community, providing free parenting guidance for women who will become mothers, enhancing mothers' parenting knowledge preparation, and removing psychological obstructions to make them stay in good mood. It can also provide opportunities for the prospective mothers to meet more mothers to exchange parenting knowledge together. Second, increase the popularity and improvement of maternity insurance. Implement the maternity insurance system. Finally, increase the development and supervision 
of early education and nurseries. The government should take measures to improve the functions of the community, popularize and standardize early education institutions and nurseries, and gain the trust of more families ${ }^{[6]}$.

\section{ACKNOWLEDGEMENT}

This article is a School Project of Chongqing University of Education: Research on the Flow Mechanism of Early Education Teachers of Young Children of 0-3 Years Old (KY201913C) and a staged research achievement of the Technology Collaborative Innovation Platform of Chongqing University of Education, "Family Education Research Center for Children Aged 0-6" (16xjpt03).

\section{REFERENCES}

[1] Hong, X., Zhu, W. T. (2020). Construction of a Family Support System for Infant and Young Children Care under the Universal Two-child Policy-An Investigation and Analysis Based on Parenting Stress,
Mothers' Dilemma and Social Support. Journal of Educational Studies, 16: 35-42.

[2] Guo, G. (2019). Practice of Fatherhood under Day Care Services of Young Children Aged 0-3. China Youth Study, 11, 85-92.

[3] Li, P. L. (2016). Analysis of Factors influencing the Direct Economic Cost of Child Rearing in China. Journal of Fujian Administration Institute, 5, 103-112.

[4] Li, M. Y., Qimu, T. D., Zhang, Q., Wang, L. X., Guan, Y. (2017) A comparative analysis of parental stress and social support of parents in China and Japan in the era of low fertility. Preschool Education Research, 2017 (03): 46-54.

[5] Gao, W., Zhu, J. H., Fang. Z. (2020). The effect of father 's participation in parenting on the aggressive behavior of primary school students: Partial mediation effect of mother 's parenting pressure. Psychological Development and Education, 36, 84-93.

[6] Li, Y. F., Yuan, Y. L., and Wang, L. Y. (2019). Current Situation and Influencing Factors of Parenting Stress of Mothers of Young Children Aged 0-3. Studies in Preschool Education, 9,68-80. 